\title{
VOTE BUYING IN NIGERIA \\ An Assessment of the 2007 General Elections
}

\author{
N D Danjibo \& Abubakar Oladeji
}

\author{
Dr Danjibo and Abubakar Oladeji are Research Fellows with the \\ Nigerian Institute for Social and Economic Research Ibadan \\ PMB 5, University of Ibadan Post Office, Ibadan, Nigeria \\ Tel: Danjibo +080 52289349 \\ e-mail: danjib@yahoo.com \\ Tel: Oladeji +080 55862926 \\ e-mail: aoladeji079@yahoo.com
}

\begin{abstract}
Nigeria's electoral process has been confronted with daunting and enormous challenges which bedevil the conduct of elections considered free, fair and acceptable both within the country and internationally. But a more crucial problem in Nigeria's electoral system is that of vote buying (and vote selling). This study exposes the nature of vote buying (and selling) as a form of electoral malpractice whose root causes may be linked to illiteracy, poverty and a zero-sum game of political exclusion. Overall, Nigeria needs to fight illiteracy, poverty and the practice of constitutional engineering if it is to be able to hold credible elections.
\end{abstract}

\section{INTRODUCTION}

One of the fundamental problems of the democratisation process in Nigeria is the conduct of free, fair and acceptable elections. Virtually all the elections conducted in the history of Nigerian politics have been characterised by one form of electoral problem or another. The 1959 election was widely condemned as unacceptable by most of the opposition parties (Post 1964; Ojigbo 1980; Dudley 1973). The 1963 / 64 election was also beset with problems and serious challenges, especially in the Western region and the middle belt, which crisis led to the collapse of the First Republic (Ingham 1997; Diamond 1996; Anifowose 2006); the opposition contested the results of the 1979 election, creating a crisis which led to the military takeover of the government (Joseph 1999). The 1993 elections, 
adjudged the freest and fairest, were annulled by the military government of Ibrahim Babangida. The 1999 elections left the Nigerian people with no choice the president who emerged was the product of the military. The 2003 elections were widely acclaimed to be massively fraudulent (Catholic Secretariat 2003), while those in 2007 were regarded as the worst ever conducted, at least partly because of the move from votes allocated by the electoral body to direct rigging.

Among the problems associated with the conduct of elections in Nigeria are the electoral body, the electoral system and the electoral process. Nigeria has never had a truly independent electoral commission - the process of establishing them makes them part of the executive arm. For example, the 1999 Constitution vested in the hands of the president the responsibility for appointing the officers of the 'Independent' National Electoral Commission (INEC), which gives him the opportunity to appoint party loyalists. Hence, the general perception is that the INEC is a federal agency, rather than a federalising institution.

The electoral system itself cannot be said to meet the demands of Nigerians. The first-past-the-post (FPTP) system and the secret ballot allow for all manner of irregularities and prevent adequate representation, which robs citizens of their right to elect credible politicians. In other words, both the FPTP and the secret ballot lead to ballot wastage, as only the winners (who often win a minority of votes) are allowed to rule. In addition, the secret voting system allows for the manipulation of votes by the political elite and electoral institutions.

The electoral process is also marred by irregularities ranging from the deliberate exclusion by the electoral agency, often in collusion with the ruling party, of eligible voters from the voters' register to the conduct of elections involving all manner of ballot manipulation for favoured candidates or parties. In all this, the votes of the electorate do not count.

One of the major forms of irregularity is vote buying and vote selling. The major focus of this study, therefore, is vote buying, especially as it featured in and affected the 2007 general elections.

\section{CONCEPTUAL ISSUES}

\section{Elections}

Elections are the only acceptable institutionalised process enabling some or all of the recognised members of a democratic society to choose office holders (Olaitan 2005, p 44). As a defining characteristic of democracy, therefore, elections enable citizens to choose a government empowered by them to make and enforce laws in a given political community and within a defined territory. Through elections people choose the programmes the government will follow, as well as settle problems which divide the government and the political parties (Ofoegbu 1976, p104). 
Elections lie at the heart of representative governance, giving meaning to the modern conception of democracy (Joseph 1987). They not only constitute the mirror of a people's understanding and the level of appreciation of democratic norms (Ahamba 2002, p13) they are a defining feature of democracy. Ezeani (2005, p 414) sees elections as 'the manner of choice agreed upon by a group which enables them to select one or a few people out of many to occupy one or a number of positions of authority'. Indeed, a regime is termed 'democratic' to the extent that those who govern are chosen by those who are governed by means of free and fair elections. According to Appadorai (1975, p 187) democracy is that form of government in which the ruling power of a state is legally vested not in any particular class or classes but in the members of a community as a whole. Thus, there is an intricate link between elections and choice, because elections are about choices, either between issues or between personalities (Aluko 2003).

Elections remain the basic platform upon which liberal democracy must be built. The conduct of elections is the cause of liberal democracy, and liberal democracy is the effect of real elections. According to Ahmadu Kurfi, former secretary of the Federal Election Commission (FEDECO), which organised the 1979 elections, 'a true representative system of government absolutely depends on the integrity of elections' (Kurfi 1983). A system of government cannot be said to be representative if the conduct of elections is beset with faulty processes. 'Thus, liberal democracy implies not only an extension of the franchise but the equality of voting rights' (Ball 1990, p 115). It is not only the equality of voting rights that matters but the quality of voting. In a liberal democracy citizens must have the ultimate right to choose and substitute leadership when necessary, and this can only be achieved through the conduct of genuine elections because elections remain the only platform in democratic societies upon which leaders emerge and submerge. Therefore, the character of any society claiming to be democratic can only be measured by the type of election that produces the government of such a society. Elections are to the citizens and the general public who have the vote what guns are to the military. As the military use guns to topple and establish military and authoritarian governments, voters use the power of the ballot. Liberal democratic theory of representation is based on rationalism. Accordingly, 'Man is a creature of reason; he can identify his own interests and his own opinions, and is aware of the wider claims of his community. He will therefore use his vote in an intelligent fashion and is consequently entitled to share in the selection of representatives' (Ball 1990, p 115).

According to Levi Obijiofor, a Nigerian political analyst,

Elections ought to be an opportunity for every Nigerian of voting age to send a strong message across to politicians at every level of 
government - federal, state and local council. If voters believe that some politicians who are qualified to contest elections have performed wonderfully well, then, by all means, voters should be given the opportunity to express their appreciation by extending the mandate given to those politicians ... If however, voters feel that politicians and the party in power have achieved little or nothing, then voters have the obligation to dismiss the politicians through the ballot box, voters would be making a statement that they would have had enough of the unfulfilled promises, and that they had decided to withdraw the mandate given to those unimpressive political leaders. Voters cannot be denied their natural rights to participate in the political process. It is also a fundamental human right of every citizen who wishes to participate in the process of electing political leaders.

The Guardian 6 April 2007, p 49

If humans, therefore, are beings endowed with rationality, they are expected to utilise their votes wisely to effect positive changes in society. Once they are denied this privilege, especially in a liberal democratic state, they are not only robbed of the opportunity to effect the desired changes but are subjected to political slavery.

\section{ELECTORAL MALPRACTICES}

Citing copiously from the Encyclopedia Britannica (1980, p 534), Bello-Imam (2007) posited that there are several ways in which electoral processes can be vitiated. The most significant of these is corruption.

Corruption of electoral practices is of course, not limited to bribery or intimidation of the individual voter. The possibilities are endless, ranging from the dissemination of scurrilous rumours about candidates, and deliberate false campaign propaganda, to tampering with the election machinery by stuffing the ballot box with fraudulent returns, dishonest counting or reporting of votes, and total disregard of electoral outcomes by incumbent officeholders...

Section 131 (1\&2) of the 1999 Constitution of Nigeria specified forms of vote buying as electoral offences under the sub-title 'Bribery and Conspiracy', which are treated as offences.

(1) A person who:

(a) directly or indirectly by himself or by any other person on his behalf, gives, lends or agrees to give or lend, or offers, promises; 
(b) promises to procure or endeavour to procure, any money or valuable consideration to or for any voter, to or for any person on behalf of any voter, or to or for any other person, in order to induce any voter to vote, to refrain from voting, or corruptly does any such act on account of such voter having voted or refrained from voting, at any election;

(c) directly or indirectly, by himself or any other person on his behalf, corruptly makes any gift, loan, offer, promise, procurement, or agreement to or for any person, in order to induce such person to procure or to endeavour to procure the return of any person as a member of a Legislative House or to an elective office or the vote of any voter at any election upon or in consequence of any gift, loan, offer, promise, procurement or agreement, corruptly procure, or engages or promises or endeavours to procure, the return of a person as a member of a legislative house or an elective office or the vote of any voter at any election;

(d) ...;

(e) advances or pays or causes to be paid any money to or for the use of any other person, with the intent that such money or any part thereof shall be expended in bribery at any election, or who knowingly pays or causes to be paid any money to any person in discharge or repayment of any money wholly or in part expended in bribery at any election;

(f) after any election directly, or indirectly, by himself or by any other person on his behalf receives any money or valuable consideration on account of any person having voted or refrained from voting, or having induced any other person to vote or refrain from voting or having induced any candidate to refrain from canvassing for votes for himself at any such election.

Elections in Nigeria have, since independence, been increasingly contentious and confrontational, largely because of acts such as election rigging and manipulating the rules of the electoral contest, which have covertly or overtly corrupted the electoral procedures. Indeed, one outstanding feature of Nigeria's various attempts at political succession is electoral malpractice. Mackenzie (1958, p 14) listed four conditions for the holding of free elections:

(i) An honest, competent, non-partisan administration to run elections;

(ii) Ageneral acceptance throughout the political community of certain rather vague rules of the game, which limits the struggle for power because of some unspoken sentiment that if the rules are not observed more or less faithfully, the game itself will disappear amid the wreckage of the whole system; 
(iii) A developed system of Political Parties, traditions and teams of candidates before the electors as alternative between which to choose; and

(iv) An independent Judiciary to interpret the electoral laws

A critical evaluation of electoral experiments in Nigeria shows that these conditions are often absent. Indeed, there is an avalanche of literature on the problem of conducting free and fair elections in the country and most scholars who have written about elections in Nigeria have been emphatic that elections have hardly ever been free or fair. Edwin Madunagu (2003, p 63), for instance, declared: 'my finding is that every election in Nigeria since independence has tried to perfect the electoral malpractices or forms of election rigging employed in the preceding election, while introducing new ones'.

Clearly the absence of free polls and fair elections in Nigeria has implications for the political choices of its citizens. No doubt this political environment will continue to shape the electoral behaviour of Nigerians for a long time to come because research has shown that voting behaviour is often affected by the voter's political environment (McLean 1976, p 47).

Essentially, therefore, the phrase 'free and fair election' has been so abused in Nigeria that it has almost become meaningless as a tool of analysis. In the case of the 2007 general elections it is disheartening that most of the observer groups, both domestic and international, agree about the specifics of what transpired, differing only as to whether the endemic rigging attempts and sporadic violence rendered the process invalid or left it broadly credible.

In view of the foregoing, electoral malpractices can occur when:

- citizens are not free to contest an election, to campaign for votes, and to register as voters;

- there is no equality between voters, that is, when some people's votes are made to carry more weight than others;

- political parties are not free to sponsor candidates and canvass for votes in a truly competitive sense;

- there are imbalances in territorial units of representation;

- those entrusted with the conduct of election are agents of or are subject to direction by any of the contestants;

- the contest does not follow accepted rules;

- the contest gives some people a particular advantage;

- the contest does not reflect the true feelings of the people;

- the results are biased 
Globally, there is a link between the electoral process and its rules and the stability of the political process. Many observers have asserted that the collapse of Nigeria's previous republics was not totally unconnected with the election-related crises that pervaded the political system during these periods (Graf 1979; Jinadu 1994; Tyoden 1994). In the words of Tyoden (1994, p124), 'the tendency by particularly the ruling party at the centre to expand its sphere of influence in the country by all means fair or foul was a major reason for the collapse of the first and second republics'. Furthermore, the loquaciousness of leading politicians of the period, who threatened to 'capture' states hitherto controlled by opposition parties, not only poisoned inter-party relationship but made nonsense of the whole democratic process as electoral malpractice such as rigging, intimidation of opponents, buying of votes, and so on, became the order of the day (Tyoden 1994).

Table 1 reveals that electoral malpractice manifests in three stages - before, during and after the election, though this distortion of the democratic process is more frequent before and after than during the election. It should also be noted that all the dimensions of electoral malpractice manifested in one way or another during the 2007 elections. For instance, the pre-election dimensions took various forms, such as INEC's failure to carry out successfully the three-day exercise in which temporary registration slips were to be exchanged for voter cards, thereby disenfranchising many eligible voters. During the election, malpractice throughout the country included late opening of polls, logistical difficulties, a lack of secrecy of ballots, the inadequacy of polling infrastructure, and the possibilities of fraud and fatigue-related mistakes engendered by the drawn-out process of collation. We would add also the inappropriate siting of some polling stations.

Over all, the logistical problems were most pronounced during collation at ward level, where lights, furniture and transportation were in short supply.

Although one cannot fairly describe the events on polling day as being thoroughly rigged, except in some areas, the role of money in buying influence prior to the conduct of elections cannot be ignored. A further cause for concern is the distribution of cash to electoral officials who participated in rigging and ballot stuffing in exchange for money.

In states where vote buying actually took place party agents in a particularly close-run ward were reported to have handed out $\$ 200$ notes to voters in the queue. In some states party agents also gave out voter cards to their supporters. In other states underage people were paid to vote. A highly disturbing case was the report that compromised INEC officials were used to distribute double the number of ballots to supporters of incumbents. In states where this scenario occurred many INEC officials reportedly turned their jobs into a business opportunity whereby parties bought books of ballot papers for a marketfixed price. 


\section{Table 1}

\section{Dimensions of Electoral Malpractice}

\begin{tabular}{|c|c|c|}
\hline Pre-Election & Election & Post-Election \\
\hline $\begin{array}{l}\text { Defective registration } \\
\text { of voters }\end{array}$ & Ballot box stuffing & Falsification/alteration of results \\
\hline $\begin{array}{l}\text { Wrongful disqualification of } \\
\text { selected candidates }\end{array}$ & $\begin{array}{l}\text { Intimidation by law } \\
\text { enforcement agents (in } \\
\text { order to favour particular } \\
\text { candidates/parties) }\end{array}$ & $\begin{array}{l}\text { Illegal disqualification of elected } \\
\text { candidates }\end{array}$ \\
\hline Shoddy preparation & $\begin{array}{l}\text { Allocation of votes } \\
\text { where no voting took } \\
\text { place }\end{array}$ & $\begin{array}{l}\text { Wrongful declaration of elected } \\
\text { candidates/ unauthorised } \\
\text { announcement of election results }\end{array}$ \\
\hline $\begin{array}{l}\text { Party fielding } \\
\text { unqualified candidates }\end{array}$ & $\begin{array}{l}\text { Connivance of parties with } \\
\text { electoral body for } \\
\text { the purpose of } \\
\text { falsifying results }\end{array}$ & $\begin{array}{l}\text { Parties who fielded no candidates } \\
\text { declared winner }\end{array}$ \\
\hline $\begin{array}{l}\text { Illegal printing of voters' } \\
\text { cards by parties with } \\
\text { the aim of using then } \\
\text { to rig the election }\end{array}$ & $\begin{array}{l}\text { Over-voting (more votes } \\
\text { than registered } \\
\text { voters/population) }\end{array}$ & Inflation of votes \\
\hline $\begin{array}{l}\text { Creation of spurious polling } \\
\text { booths in hidden houses in } \\
\text { advance of the election } \\
\text { date. INEC agents issuing } \\
\text { materials, including ballot } \\
\text { boxes, to these booths on } \\
\text { payment of an agreed sum } \\
\text { of money }\end{array}$ & $\begin{array}{l}\text { Physically intimidating } \\
\text { voters for the purpose of } \\
\text { scaring them away so as } \\
\text { to to be able to rig } \\
\text { elections }\end{array}$ & $\begin{array}{l}\text { INEC says the name of a candidate } \\
\text { with the highest votes is not in its } \\
\text { file (even when such a } \\
\text { candidate has paid the } \\
\text { required fees) }\end{array}$ \\
\hline $\begin{array}{l}\text { Non-display of voter } \\
\text { registration by INEC } \\
\text { at the appropriate time }\end{array}$ & $\begin{array}{l}\text { Deliberate refusal to supply } \\
\text { election materials to } \\
\text { strongholds of opponents / } \\
\text { opposition parties }\end{array}$ & $\begin{array}{l}\text { A party's victory withdrawn } \\
\text { by the electoral body on the } \\
\text { allegation that it fielded } \\
\text { non-indigenes, although } \\
\text { INEC had earlier issued } \\
\text { a clearance certificate to } \\
\text { the candidate }\end{array}$ \\
\hline $\begin{array}{l}\text { Deliberate } \\
\text { disenfranchisement } \\
\text { of eligible voters }\end{array}$ & & $\begin{array}{l}\text { Official manipulation of electoral } \\
\text { process against a party/ } \\
\text { some parties }\end{array}$ \\
\hline \multirow[t]{2}{*}{$\begin{array}{l}\text { Non-serialisation of } \\
\text { ballot papers }\end{array}$} & & $\begin{array}{l}\text { A party/candidate wins at election } \\
\text { tribunals, but the } \\
\text { government refuses to swear } \\
\text { in the winner }\end{array}$ \\
\hline & & $\begin{array}{l}\text { Outright cancellation of electoral } \\
\text { process, after results have been } \\
\text { wholly or partially released }\end{array}$ \\
\hline
\end{tabular}

Source: Compiled by authors 2007 
In many parts of the country rural communities rigged their own polls, without necessarily changing the outcome, by allocating all the unused papers between the candidates at the end of the day, thus inflating the numerical importance of their community in order to secure future access to state development assistance. To achieve this rigging of size though not of votes, a number of traditional dignitaries reportedly colluded with politicians and INEC to subvert the democratic process.

The authorities who administered the 2007 elections can be criticised in a number of ways. First, while INEC, perhaps inevitably, takes the lion's share of the blame for mismanagement, the incumbent administration, which used the late release of funds and control over senior appointments to make INEC's independence of action less than complete, also shares the blame. Indeed, the late release of funds compromised INEC's logistical effectiveness. The manner in which the initial voter registration was conducted also attracts some share of the blame, as does the confusion over the supplementary exercise.

Candidate selection is another way in which an election can be compromised long before it takes place. What INEC can rightfully be blamed for is the inadequate training of polling officials, the failure to make copies of the Electoral Act widely available, widespread neglect of the welfare of its own staff, and the lack of awareness - to some extent corrected before the elections - of how to set up satisfactory polling booths. At the grassroots level INEC was compromised at times by its own officials, either in their partiality or in their willingness to profit from their position and be swayed by bribery.

\section{THE 2007 ELECTIONS}

On 14 April elections were conducted throughout Nigeria for the president and vice-president, the 109-member Senate and the 360 members of the House of Representatives. These were followed on 21 April by elections for governors, deputy governors, and members of houses of assembly of the 36 states of the federation. The elections took place under the incumbency of the Peoples Democratic Party (PDP)-led administration, with President Olusegun Obasanjo doing everything possible to return his party to power.

The federal-government-controlled INEC, under the chairmanship of Professor Maurice Iwu, was mandated to conduct and supervise (or to supervise the conduct of) the elections, which were contested by 50 parties. In an important sense this large number of parties was the outcome of a legislative victory over the executive's attempt to constrict the political space.

On 22 January 2002 the Senate passed a new Electoral Act, repealing the Act signed into law by President Obasanjo on 6 December 2001, which had contained 
the controversial s 80(1), which dealt with the conditions for party registration. Former President Obasanjo, in collusion with the PDP dominated National Assembly, had attempted to raise the percentage of political associations seeking registration. Clause 80 of the Electoral Act 2001 stipulated that: 'Where a party, at the close of nomination for a general election, fails to sponsor at least 15 per cent of the candidates for Councillorship, Council Chairmanship and State Houses of Assembly, respectively throughout the federation, spread among two-thirds of the state of the federation and Federal Capital territory, it shall not participate in the general elections.' The new clause states that: 'A new registered political party shall first participate in Local Government Council election and win at least 10 per cent of Councillorship and Chairmanship position throughout the federation and spread among two-thirds of the States of the federation and the Federal Capital Territory to be eligible to participate in federal elections.' This clause was seen as a diabolical plot to deny Nigerians the right to choose to which party they would like to belong.

However, thanks to the judiciary, which liberalised the political space by enabling more political association to register as parties, 50 parties were recognised, thus strengthening Nigeria's democracy and making it consistent with the practice of Western liberal democracies, where an array of opposition parties is considered the norm (Ademolekun 1985, p 2). The existence of a thoroughly liberalised political space is an important medium through which the electorate makes a choice among the many political parties and the many issues for which the parties stand.

\section{CHARACTER OF THE 2007 GENERAL ELECTIONS}

The 2003 general elections were massively rigged, but there is no appropriate adjective to describe the degree of fraudulence during the 2007 elections, which were condemned by both local and international observers as falling short of national and international standards. President Umar Yar'Adua has himself acknowledged the deficiencies and has initiated electoral reforms (Nigerian Tribune August 2007). Sam Egwu (2007, p 9) has succinctly described the anomalies of the 2007 general elections in relation to the 2003 general elections:

The 2007 elections were characterized by additional problems such as deliberate poor handling of the logistics of voter registration, distribution of election materials and transmission of results; doubtful integrity of the ballot as polling booths were not available outside the state capitals; gross undersupply of voting materials in places where opposition parties were perceived to be strong; open thumb- 
printing of ballot papers; and allocation of votes to candidates and political parties.

The report of the European Union Election Observer Mission (EUEOM) asserted that:

The 2007 federal elections have fallen far short of basic international and regional standards for democratic elections. They were marred by poor organization, lack of essential transparency, widespread procedural irregularities, significant evidence of fraud, particularly during the result collation process, voter disenfranchisement at different stages of the process, lack of equal condition for contestants and numerous incidence of violence. As a result, the elections have not lived up to the hopes and expectations of the Nigerian people and the process cannot be considered to have been credible.

The Guardian 24 April 24 2007, p 10

These assessments underscore the fact that the electoral processes in Nigeria are beset with unacceptable irregularities which need serious attention.

\section{VOTE BUYING}

Simply defined, vote buying is the exchange of votes for money or any material benefit either actual or potential. However, this definition suggests that votes are market commodities which the merchant is ready to dispose of for gain. If this is the case, it is not ethically wrong to buy and sell votes. Sha (2006, p 124) defines vote buying as 'any form of persuasion in which financial gain is suggested by one person to another with the intention of influencing a person's vote'.

Vote buying can also be defined as: 'A gift or gratuity bestowed for the purpose of influencing the action or conduct of the receiver; especially money or any valuable consideration given or promised for the betrayal of a trust or the corrupt performance of an allotted duty, as to ... a voter ...' Bello-Imam (2007, p 4) sees vote buying as a form of 'bribery consisting of money or other rewards for voting as directed'.

\section{Forms of Vote Buying}

There are different forms of vote buying, apart from those specified in the 2006 Electoral Act. Among them are:

- direct inducement of the electorate with money to influence votes in favour of a particular political party or candidate; 
- inducement of local political elites with money or materials in order to gain the block vote of a particular constituency;

- providing wards or electoral constituencies with materials such as clothing or food with the intention of getting their votes;

- purchasing cars or motorbikes, building houses and providing contracts for traditional rulers and local elites in order to get the votes of their subjects;

- paying political thugs to intimidate and harass the electorate to force them to vote for a particular political party or candidate;

- paying political thugs to snatch ballot boxes;

- paying security agents to aid in electoral fraud;

- paying electoral officials to aid in electoral fraud.

\section{THEORETICAL FRAMEWORK: MONEY AND POLITICS}

Money is an essential aspect of politics. According to Sobel $(1974, \mathrm{p} 1)$ 'money has always been a major weapon in the politician's arsenal'. Money drives politics and without it politics cannot survive. In 1974 United States Senator Edward Kennedy said: 'For centuries, money and public service have been a corrosive combination in political life' (cited in Sobel 1974, p 2); and in The Prince, Machiavelli observed that 'As a general rule, those who wish to win favor with a prince offer him the things they most value and in which they see that he will take most pleasure' (cited in Sobel 1974, p 2). Thus, electoral victory becomes a critical condition for 'the patronage, the triumph of an interest or an ideology, and the social and psychological reward that motivate involvement' (Beck \& Sorauf 1992, p 228).

In Nigeria large chunks of money are necessary to influence the electorate during party campaigns. This is because there is a general belief that Nigerian politicians are neither accountable nor responsive because they do not fulfil their promises, so the only time they can be made to commit resources to the electorate is during their party campaigns. This belief contains some element of truth because most Nigerian politicians do not even visit their constituencies after they have been elected.

Sadly, the negative effect of moneybag politics in Nigeria has social consequences, including socially deviant behaviour. Davies (cited in Ojo 2006, p 106) observes:

Paradoxically, money itself has become a dominant factor... money seems to have taken the centre stage in the political process in most countries and in Nigerian politics. It is, sadly, now playing an increasingly critical role. It even appears to be so dominant in the electoral process to such an extent that the word [sic] 'money politics' with a pejorative connotation has crept 
into the country's political lexicon. It is now a critical variable when assessing the level of political corruption in the country.

There are enormous financial challenges facing people, especially women, who wish to offer their services to the electorate.

Over $90 \%$ of the [women] aspirants were faced by the challenge of inadequate resources to support their registration, establishment of offices, maintenance of campaign structures and basic logistics. Even the successful aspirants indicated the challenge of the monetized processes they had to pass through to get nominated and go to the level of the primaries. Payment for delegates was a major issue many of them were unable to meet up with against some of the 'wealthier' opponents.

WRAPA 2003, p 17

Increasingly, electoral politics is becoming so expensive that many a genuine politician is excluded from participating for lack of money, which makes it possible for the very rich to hijack the electoral process (Ojo 2006). '[I]n Nigeria, winning an election is for the highest bidder' (Nigerian Tribune 2 April 2004, p 21), so much so that 'what we actually call democracy is not democracy. It is a system of mental and physical cheating, and buying of votes in the political open market (Nigerian Tribune 2 April 2004, p 21). This is why elected officials indulge in corrupt practices in order to meet the financial demands of political participation. For example, during the 2003 general elections the then Minister for Women's Affairs, Hajia A'isha Ismail, lamented the amount of money needed for women to participate in the election. According to the minister about '3.8 billion Naira is required for Nigerian women vying for elective offices in this year's general election' (New Nigeria 25 February 2003, p 24). During the 2007 elections the Political Parties Alliance, an umbrella of 22 political parties, accused the PDP, the All Nigeria Peoples Party (ANPP) and the Action Congress (AC) of exceeding the allowance set down in the Constitution, contrary to ss 87, 91, 92, 93 and 94 of the Electoral Act of 2006 (The Guardian 5 April 2007, p 7), a default against which INEC has not been able to take action because the party which commits the offence most often is the PDP and the financial and administrative control of the electoral agency is the exclusive preserve of the governing party.

\section{VOTE BUYING DURING THE 2007 ELECTIONS}

The phenomenon of vote buying in Nigerian electoral politics is empirically elusive. This is not only because few in-depth studies have been carried out but 
because it is sometimes accepted as a normal practice. Even the media have not kept a record of the phenomenon, essentially because, like corruption, it is difficult to track. However, there is a general belief that vote buying is part and parcel of the country's electoral system.

While it is not possible for us to give an account of all the acts of vote buying that took place during the 2007 general elections there was substantial evidence that it did indeed take place. This study relies on some key informants from across the country who testified to the fact that vote buying occurred in several constituencies before and during the election. Because of the sensitive nature of the phenomenon most of our informants have asked to remain anonymous. The paper also draws on copious references to vote-buying activities during the 2007 general elections from the report on the elections compiled by the Justice Development and Peace Commission of the Catholic Secretariat in Nigeria. The Catholic Church was an unbiased observer of the 2003 and 2007 elections. It sent out 22000 carefully trained observers who subsequently collated their findings (Catholic Secretariat 2007, p 11).

Nigeria is non-constitutionally but politically divided into six geo-political zones, namely the Northwest, The North-Central, The Northeast, The Southwest, Southeast And The South-South. The Northwest comprises Kaduna, Kano, Katsina, Kebbi, Jigawa, Sokoto and Zamfara states. The North-central comprises Benue, Kogi, Kwara, Nassarawa, Nigeri, Plateau and the Federal Capital Territori (Abuja). The Northeast zone consists of Adamawa, Bauchi, Borno, Gombe, Taraba and Yobe states. The Southwest zone consists of Ekiti, Lagos, Ogun, Ondo, Osun and Oyo states. The Southeast comprises Abia, Anambra, Ebonyi, Enugu and Imo states. The South-south comprises Akwa-Ibom, Bayelsa, Cross-River, Delta, Edo and Rivers states. The study highlights the phenomenon of vote buying and selling in each of these zones.

\section{Southeast Zone}

In the Southeast zone political 'party thugs and paid agents' took over voting activities in most parts of Ebonyi State as INEC officials were barely seen in most of the polling units during the gubernatorial election. In Enugu State 'the Peoples Democratic Party had bought over the majority of INEC officials and party security officials which [sic] were seen collecting bribes from party stalwarts'. In Imo State 'Money was given in exchange for voters' cards in polling stations like 006 Ugbele ward, Ideato South as well as in all the stations in Nkwerre LGA'. Vote buying also occurred in IM/OW / Primary School New Owerri / 006; IM/OW / shell camp/ 001; IM/OW/Alvan/006 and IM/OW/Orij/001. In ward 3 booth 007 of Lude Ahiazu Local Government Area (LGA), INEC officials traded ballot papers with 
party agents depending on the amount given. In Mbaise Local Government Area 'there was infighting between PDP supporters and agents over money sharing which was the order of the day' (Catholic Secretariat 2007, pp 29-32).

\section{South-south Zone}

In the South-south party agents in Calabar municipality removed ballot boxes after bribing INEC officials. 'Bribery of voters through PDP was equally reported e.g. in Ika South LGA, W008, Polling Code 004 and 005, and 008 and 009'. In Edo State the entire voting was one-sided in favour of PDP as police officers, INEC officials and party agents were bribed' in Ubiaja town of Esan South-east Local Government Area during the gubernatorial election (Catholic Secretariat 2007, pp 34-5).

\section{Southwest Zone}

In this zone 'party officials hung around most polling units and bribed voters with money to influence their votes'. In Ogun State (the home state of ex-President Olusegun Obasanjo) '[s]ome politicians were observed canvassing for votes while voting was on and even giving out money to bribe voters. In Odogbolu Local Government, bribery of officials was noticed at Idowa, Ward 8, PC 003; Ward 11, PC 001 and 003 Imoru and Emuren respectively. In Yewa South Local Government, voters were bribed with $\$ 200: 00$ (equivalent of $\$ 1.5$ ) each by party agents in ... Ward 8, PC 001 and 002 at Amulekangbo' during the presidential and National Assembly elections of 21 April. In Osun State 'INEC officials and security personnel were bribed to allow multiple votes' in Osun/Ife Central, Ward 007; Osun/Ife North, Ward 004; Osun/Ilesha East, Ward 003; Osun Boripe, Ward 007; Osun/Ife South, Ward 001; Osun/Ifelodun, Ward 005 and Osun/Ilesha East during the Presidential / National Assembly election. In Oyo State a PDP stalwart was seen bribing INEC officials, party agents and observer members of the Civil Liberty Organisation (CLO) who allowed multiple voting in Ward 10, Unit 11 of Egbeda Local Government Area (Catholic Secretariat 2007 pp 37-43).

Similar incidents were said to have occurred in Omi-Adio and in Iseyin, both in Oyo State. In the case of Iseyin a candidate accused the police of not keeping to the terms of a contract to help him win the election after collecting \#10 000 each to do so. Furthermore, a former local government chairman in Oyo State was severely beaten by the political thugs of Lamidi Adedibu and AlaoAkala for failing to use the money he had collected to buy the votes of voters in his constituency (interview with participant observers).

On the day of the gubernatorial/ state house of assembly elections the deputy 
national chairman, Southwest, of the PDP, Chief Olabode George, was said to have stormed the INEC office in Lagos with bags of 'Ghana-must go', ${ }^{1}$ with the intention of bribing the resident electoral commissioner to manipulate the results in favour of the PDP. However, the commissioner not only refused but ordered George off the premises. 'Bode George left the Lagos office of INEC threatening to deal with the Resident Electoral Commissioner should the PDP fail to win Lagos State' (personal interview with an official election monitor). As it turned out, the PDP lost to the AC. This incident helped to highlight what may have accounted for the sweeping 'victory' of the PDP in the massively flawed elections.

\section{North-central Zone}

According to reports there was 'sharing of money to win votes from eligible voters' in Benue State during both the gubernatorial and presidential elections. At Makurdi, 'an INEC official who refused to take a bribe was arrested and detained at the Government House'. In Bokkos Local Government Area Anguwan Hausawa Ward 003, of Plateau state, 'a man and his wife were caught issuing out illegal papers for both [sic] Presidential, Senate and House of Representatives [sic]. They also gave the sum of $\$ 1000$ to each person who collected the ballot papers.' In Nassarawa State 'Bribery of INEC officials was noticed in the following places: Makama ward, Bamai Sule (rice mill), and in Chiroma ward'. In Niger state irregularities included 'bribery, campaigning, snatching of ballot boxes, thumbprinting and stuffing of ballot boxes' (Catholic Secretariat 2007, pp 44-8). In Kwara State opposition political parties accused the PDP and Governor Bukola of paying the security agents and INEC to perform criminal acts. According to the opposition parties 'There is no denying the fact that the government in power mobilized INEC, the police and the military to intimidate, harass and kill innocent people who had looked forward to exercising their rights' (The Guardian 20 April 2007, p 6).

\section{Northeast Zone}

In Taraba State, especially in the Tikakri ward of the Takum Local Government Area, 'bribing of security agents, multiple and late voting was the order of the day'. In Borno State bribing of voters and INEC officials was recorded. In 'Jambari ward, polling unit 51 behind army barracks, ANPP agents brought voters' cards

1 In the early 1980s during the extradition of illegal resident Ghanaians from Nigeria the large bags used to convey their belongings became known in Nigeria as 'Ghana-must-go' bags, which became a popular way of describing corruption in Nigeria, in which bags of money are used for bribery. 
and shared to people who had none so that they could vote for their candidate. As a matter of fact, vote buying in Borno state started during the pre-election campaigns when it was reported that the incumbent Governor, Ali Modu Sheriff was video-taped throwing bundles of money to people on the street while on a campaign trail. They went further to bribe voters in the presence of the security agents' (The Guardian 6 September 2007, p 27). In Baba Tanko, unit 1 of Bauchi state, 'a PDP agent was seen bribing voters to vote for her party'. An ANPP agent also bribed voters to vote for his party at Gwallameji polling unit. The same act of bribery was reported at Idris unit. There were 'reported cases of PDP agents bribing voters to vote for their party' in places like Birshi Fulani, Sarkin Pawa, Gwallameji, Baba Tanko and Dandango 11. There were reported cases of bribery of voters and INEC officials in Gombe state. There was also distribution of money to voters by PDP agents in places like Kofar Ibrahim, Sokoto Herwagana quarters (The Guardian 6 September 2007, pp 49-51).

\section{Northwest Zone}

Vote buying took place in most parts of northwestern Nigeria, especially during the campaign period, in Sokoto, Zamfara, Kebbi and Jigawa. Wealthy political parties and gubernatorial candidates tried to bribe voters by buying truckloads of bicycles and motorcycles which they distributed to both party loyalists and other voters. In Zamfara State the agency in charge of poverty alleviation activities, Zamfara Poverty Alleviation (ZAPA), was used by former Governor Ahmed Yerima to distribute funds and motorbikes. Yerima also used 60 official cars for his campaign rallies (Bello-Imam 2007, p 19). Some emirs who had received inducement from politicians also flouted the rule of non-partisanship and canvassed openly for votes for their political benefactors.

\section{CAUSES OF VOTE BUYING}

There are several reasons for the prevalence of vote buying.

- Illiteracy: In the words of Ajakaiye et al (2002, p 285) the low level of education contributes to low political awareness thus making it easy for the state to manipulate the poor majority and for greedy and self-seeking politicians to fool the electorate.

- Poverty: Poverty makes a people powerless and easily susceptible to political manipulation. People who are poor and whose next meal is not guaranteed can easily sell their consciences/votes for any amount (cash, kind, etc) offered (Ojo 2006). With Nigeria's high level of poverty (some studies 
indicate that the proportion may be as high as $75,5 \%$ ) it is not unexpected that the poor will become vulnerable to vote selling.

- Nature of Politics: The nature of politics as a winner-takes-all affair and a means for self aggrandisement results in politicians deviating from moral principles to secure victory.

\section{IMPLICATIONS OF VOTE BUYING AND SELLING FOR THE CULTURE OF DEMOCRACY}

Vote buying and selling have dire consequence for democratic governance. First, they make it impossible to elect leaders freely and fairly, suggesting that elective positions can be bought and casting doubt on the legitimacy of government. They are also an indictment of government's ability to instil the electoral discipline that gives the electorate the right and opportunity to choose credible leaders.

They also have implications for the responsiveness of elected officials. Voters who engage in vote selling have, ipso facto, denied themselves the right to demand transparent and accountable leadership, as politicians who buy votes are under no obligation to be accountable to the electorate. Vote buying and vote selling can therefore be seen as a form of political entrepreneurship where politicians see themselves as investing in a greater political harvest, thereby encouraging the entrenchment of corruption in the polity, which erodes the very basis of democratic (good) governance.

\section{RECOMMENDATIONS}

- The institutional framework of INEC should be strengthened to make it a truly autonomous agency. Issues such as the appointment and funding of the electoral body should be democratised. Given that Nigeria is a federal state, the electoral body should be a federating agency not a federal government agency, as is presently the case.

- Vote buying is an electoral offence. Culprits should be brought to book and, if convicted, be sentenced to long jail terms.

- Poverty must be seriously addressed. People turn in their votes for money as a result of the abject poverty with which they are faced.

- Mass illiteracy is another reason for vote selling and buying. In this regard the government of Nigeria, civil society, faith-based organisations and the National Orientation Agency must embark on massive education of the electorate about the dangers and implications of the practice.

- The nature of electoral politics in Nigeria must change in regard to 
campaign financing, winner-takes-all politics and the open secret ballot system. There must be financial discipline in party campaigns; politics must be more inclusive than exclusive and methods of voting should change to keep up with technological advances, for instance, the use of voting machines.

\section{CONCLUSION}

Vote buying and selling debase the essence of democracy. They also erode the very basis of good governance in that they make the government neither accountable nor responsive to the wishes and expectations of the electorate. Among the causes of vote buying and selling in Nigeria are poverty, illiteracy, and the nature of politics. Vote buying and selling have serious implication for democratic consolidation and, unless there is a will on the part of the government to eradicate the phenomenon from Nigeria's electoral process good governance will remain elusive.

\section{- REFERENCES -}

Adamolekun, L. 1985. The Fall of the Second Republic. Ibadan: Spectrum Books Limited. Ajakaiye, D Olu et al. 2002. 'Role of Civil Society'. In D Olu Ajakaiye \& F O N Roberts (eds). Meeting The Challenges of Sustainable Democracy in Nigeria. Ibadan: NISER.

Ajakaye, F. 2007. 'Election 2007: Real “Do-or-Die” Affair'. Sunday Guardian 22 April. Aluko, M E. 2003. 'Election Tribunals - The Third Way'. The Punch 13 May 2003.

Anifowose, R. 2006. Violence and Politics in Nigeria: The Tiv and Yoruba Experience. Lagos: First Academic Publishers.

Appadorai, A. 1975. The Substance of Politics, 11 ed. Madras: OUP.

Ahamba, M I. 2002. 'Political Parties as Instrument for the Sustenance of Democracy in Nigeria'. The Guardian 21 August 2002. Lecture delivered at a National Assembly seminar.

Ball, A R. 1990. Modern Politics and Government. London: Macmillan Education. Beck, P A \& F J Sorauf. 1992. Party Politics in America. New York: Harper Collins.

Bello-Imam, I B. 2007. 'Critical Areas Begging for Electoral Reforms in Nigeria'. Discussion Paper delivered at NISER's workshop on 'Electoral Reforms in Nigeria', Ibadan, 24 October.

Catholic Secretariat. 2003. Final Report on the Observation of the 2003 General Elections in Nigeria. Lagos: JDPC.

_.2007. Observation Report on the 2007 General Elections in Nigeria. Lagos: JDP / CARITAS. 
Constitution of the Federal Republic of Nigeria 1999, s 131(1).

Diamond, L. 1996. 'Is the Third Wave Over?' Journal Of Democracy 7(3), July.

Dudley, B. 1973. Power and Political Instability in Nigeria. London: Frank Cass, Ibadan: NISER.

Egwu, S. 2007. 'Electoral Reforms and Democratic Consolidation in Nigeria'. Discussion Paper delivered at NISER's workshop on 'Electoral Reforms in Nigeria', Ibadan, October 24.

Electoral Act 2006 For the Conduct of the 2007 General Election in Nigeria.

Ezeani, O E. 2005. 'Electoral Malpractices in Nigeria: The Case of the 2003 General Elections'. In G Onu \& A Momoh (eds). Elections and Democratic Consolidation in Nigeria. Lagos: NPSA.

FRN. 1999. Constitution of the Federal Republic of Nigeria. Lagos: Government Printer. Graf, W D. Elections 1979. Apapa: Times Press.

Guardian, The 5 April 2007.

6 April 2007.

20 April 2007.

24 April 2007.

6 September 2007.

Ingham, K. 1990. Politics in Modern Africa. London and New York: Routledge.

Jinadu, L A. 1994. 'Competitive Elections and The Multi-party systems in Nigeria'. In O Omoruyi et al (eds). Democratization in Africa: Nigerian Perspectives Vol 1. Benin: Hima \& Himal.

Joseph, R A. 1999. Democracy and Prebendal Politics in Nigeria: The Rise and Fall of the Second Republic. Ibadan: Spectrum Books.

Kurfi, A. 1983. The Nigerian General Elections 1959 and 1979 and the Aftermath. Lagos and Ibadan: Macmillan Publishers.

Mackenzie, W J M. 1958. Free Elections. London: George Allen \& Unwin.

Madunagu, E. 2003. ‘What Voting Patterns? The Guardian 8 May 2003.

McLean, I. 1976. Political Realities: Elections. London: Longman Group.

National Bureau of Statistics. 2005. Federal Republic of Nigeria.

New Nigeria 25 February 2003.

Nigerian Tribune 2 April 2004.

21 August 2007.

Nwabueze, B. 1993. Democratization. Ibadan: Spectrum Law Publishing.

Ofoegbu, R. 1976. Government for the Certificate Year. London: George Allen \& Unwin.

Ojigbo, O. 1980. Nigeria Returns to Civil Rule. Lagos: Tokion (Nigeria) Company.

Ojo, E O. 2006. 'Vote Buying in Nigeria'. In Money, Politics and Corruption in Nigeria. IFES.

Olaitan, W A. 2005. 'Elections and the Making and Unmaking of Democracy in 
Nigeria'. In G Onu \& A Momoh (eds). Elections and Democratic Consolidation in Nigeria. Lagos: NPSA.

Post, K W J. 1964. The Nigerian General Election of 1959: Politics and Administration in a Developing Political System. London: Oxford University Press.

Sha, D P. 2006. 'Vote Buying and the Quality of Democracy under the 2002 Electoral Act'. In Money, Politics and Corruption in Nigeria. IFES.

Sobel, L A (ed). 1974. Money and Politics: Contributions, Campaign Abuses and the Law. New York: Facts on File, Inc.

Tyoden, S G. 1994. 'Party Relationship and Democracy'. In O Omoruyi et al (eds). Democratization in Africa: Nigerian Perspectives Vol 1. Benin: Hima \& Himal. Women's Rights Advancement and Protection Alternatives (WRAPA). 2003. Nigeria 2003 Elections: The Experience of Women Aspirants in Political Party Primaries. WRAPA. 